on the problem stated in the Draft Report, namely, to what extent are the properties of a star with polytropic index increasing outwards from $n_{1}$ to $n_{2}$ intermediate between those of the two polytropes with constant indices $n_{1}$ and $n_{2}$ respectively? It can be shown, comparatively easily, that the properties are intermediate at least up to the "envelope point" on the outer polytrope, defined by the family of solutions of the corresponding Emden equation.

The President mentioned the alternative methods of studying the density distribution in the case of eclipsing binaries and cepheids, and invited discussion on the subject.

Prof. Russell, Dr Kopal, Prof. Hagihara and Dr M. Schwarzschild took part in the following discussion, which dealt with theoretical and observational questions of the problem of determining information about the density distribution in the interior of eclipsing binaries, from observations of the motion of the line of apsides, and from observed ellipticities.

The Commission then discussed the subject of nuclear processes in the interior of the stars. The discussion was opened by Prof. B. Strömgren and Dr Atkinson. A summary was given of recent investigations by von Weizsäcker, Bethe, Gamow and others, with special regard to the question of possible neutron sources in the stellar interiors. In the discussion the President commented on the problem of the helium content of the stars. Prof. Russell discussed the questions of the empirical massluminosity law and the foundation of the method of spectroscopic parallaxes, and their connection with the problems of the hydrogen and helium content of the stars. Prof. Lemaitre commented on the question of the most luminous supergiants and the time-scale.

The Draft Report as printed was unanimously adopted.

\title{
COMMISSION 36 (SPECTROPHOTOMETRY)
}

Acting President: Dr M. Minnaert.

Secretary: Dr D. Chalonge.

\section{(a) Discussion OF THE DRAFt Report}

The acting Chairman brought over to the Commission the best compliments from Dr Pannekoek, who had been elected as President in 1935, and expressed regret at his absence, especially because the discussion which would be carried on is so intimately connected with his work. In the name of the whole Commission the Chairman thanked very much Dr Pannekoek for his fine Draft Report, which gives a very clear view on the present state of astrophysical spectrophotometry.

The Draft Report then came into discussion.

I. Calibration and standardization. Dr Minnaert said that, according to the proposal made at the Paris Meeting, Pt filters and Pt step-reducers were made on quartz and calibrated at the Utrecht Heliophysical Institute. Their transmissions will be measured also in the following institutions: National Physical Laboratory, Massachusetts Institute of Technology, Bureau of Standards, Physikalisch-Technische Reichsanstalt, Optical Institute Leningrad. An intercomparison of the results will be made at Utrecht. Though this work is not achieved, some reducers with preliminary calibrations were lent to Dr Allen and Dr Beals. 
Drs Barbier, Chalonge and Kienle compared, in I936 and I938, the standard tungsten lamps used in the Institut d'Astrophysique de Paris with those used at the Göttingen Observatory; these had been thoroughly calibrated at the PhysikalischTechnische Reichsanstalt. The Chairman drew attention to the desirability of such intercomparisons of the standard lamps in use in different institutions for spectrophotometric work.

Consequently, the following resolution was proposed by Drs Minnaert, Chalonge and Barbier and unanimously adopted for submission to the General Assembly:

"The Commission insists upon the importance of a mutual intercomparison of lamps, reducers and other photometric standards used in astrophysical work by different observers."

II. Continuous spectrum. The Chairman said that a modification must be brought to the Draft Report, following the new results recently published by Drs Barbier, Chalonge and their collaborators: the difference previously found by them (and stated in the Draft Report) between the gradients below and above $3700 \mathrm{~A}$., has, for the greatest part, disappeared; it was due to a small systematic error in the comparison between the hydrogen lamp, with which the stars are compared, and the standard tungsten lamp.

Dr Chalonge emphasized the desirability of extending to the southern hemisphere the spectrophotometric study of the continuous spectrum, so far confined to the northern stars, so as to obtain a homogeneous set of standard stars for spectrophotometric researches. Dr Greaves agreed with this proposal and insisted upon the fact that such studies, dealing with the whole sky, should be extended to as wide a spectral range as possible. The following resolution was proposed by Drs Chalonge and Barbier:

"The Commission proposes that the accurate photometric investigations on the continuous spectrum of bright stars, which have been so far carried on only in the northern hemisphere, should be extended, using the same methods, to the southern hemisphere, in order to constitute a homogeneous set of comparison stars for the study of fainter stars."

It was adopted by the Commission and Dr Greaves insisted upon the importance of its adoption by the General Assembly.

The Chairman then read the resolution proposed by Dr Kienle:

"In publishing spectrophotometric observations, it is important that not only gradients should be communicated, but the complete intensity measurements as a function of the wave-length. Only then will it be possible to compare the results of several observers and to estimate the influence of the different sources of error (for instance, the limited resolving power). The observations should be communicated in full, so that a later discussion of them in all respects be made possible."

The resolution was adopted.

III, IV. Lines. The Chairman read the following resolution, proposed by Dr Dunham:

"The Commission suggests that, in measurements of total absorption of stellar lines, a unit be used, defined as the light contained in a stretch of the continuous spectrum having a width equal to one-millionth of the wave-length of the line. This unit will be called the Fraunhofer, and will be abbreviated F."

Drs Menzel, Unsöld, Greaves, Redman, Minnaert, H. H. Plaskett and Stratton took part in the discussion concerning this resolution. Dr Menzel approved it. DrGreaves' and Dr Redman's opinions were that the adoption of a definite unit for the measure- 
ment of stellar lines was not actually imperative. Dr Unsöld said that researches of different kinds may require different units. According to Dr Minnaert, both theory and observations of line profiles are still in an early stage and it is better to wait three more years before adopting any resolution in this respect. Dr Menzel objected that, during these three years, important work will probably be done and that, consequently, it was better to discuss now the proposed resolution.

Finally the Commission adopted Dr H. H. Plaskett's proposal of discussing the resolution at the next meeting of the I.A.U., and Dr Stratton's additional proposal that a sub-commission, composed of a few members of the Commission, chosen by the President, should study the question in the meantime and try to emit a preliminary advice.

The Report was then adopted with the one small modification stated above.

\section{(b) LECTURES}

Dr Unsöld then addressed the meeting on the continuous absorption in the spectrum of the stars. Though it had been originally arranged that his lecture would be delivered in German, he was kind enough to use the English language at the request of the majority of the members present.

\section{Die Energieverteilung in Den kontinuterlichen Sternspektren}

\section{Von Prof. A. UNsöLD}

Wenn wir auf die kontinuierliche Strahlung einer Sternatmosphäre den Kirchhoffschen Satz anwenden dürfen, "lokales thermodynamisches Gleichgewicht", so ist deren Emission pro $\mathrm{cm}^{\mathbf{8}}$ und Frequenzeinheit, die sog.

$$
\text { Ergiebigkeit }=\kappa \cdot 4 \pi B_{\boldsymbol{v}}(T) \text {. }
$$

Dabei bedeutet $\kappa(\nu)$ den kontinuierlichen Absorptionskoeffizienten (pro $\mathrm{cm}$.) und $B_{\nu}(T)$ die Kirchhoff-Planck-Funktion für die betreffende. Frequenz $\nu$ und die Temperatur $T$ des betrachteten Volumelementes.

Die Theorie der kontinuierlichen Sternspektren können wir dementsprechend zerlegen in zwei voneinander ziemlich unabhängige Teile: $(A)$ Das atomtheoretische Problem der Berechnung des kontinuierlichen Absorptionskoeffizienten $\kappa(\nu)$ in Abhängigkeit von Frequenz $\nu$, Temperatur $T$ und Elektronendruck $P_{0}$ oder Gasdruck $P_{a}$. (B) Die Berechnung der Kirchhoff-Planck-Funktion $B_{\nu}(T)$ oder-was auf dasselbe herausläuft-der Temperatur $T$ als Funktion der Tiefe in der Atmosphäre. Dieses zweite Problem läuft hinaus auf eine Untersuchung des Energietransportes in der Sternatmosphäre. Die Hauptrolle spielt dabei ohne Zweifel der Strahlungsaustausch, "Strahlungsgleichgewicht"; in speziellen Fällen kommt daneben Konvektion in Frage. Wir können im Folgenden auf diesen zweiten Problemkreis $(B)$ nur gelegentlich eingehen und beschäftigen uns hauptsächlich (Problem $(A)$ ) mit der

\section{Theorie des kontinuierlichen Absorptionskoeffizienten $\kappa$.}

Die kontinuierliche Absorption in einem teilweise ionisierten Gas (Plasma) setzt sich zusammen aus:

(I) Seriengrenzkontinua, d.h. Übergängen zwischen "diskreten" und "kontinuierlichen" Quantenzuständen bzw. Ellipsen- und Hyperbelbahnen. (Bound-free transitions; Photoionisation und Rekombination.) 
(2) Bremsspektrum, d.h. Übergängen zwischen zwei "kontinuierlichen" Quantenzuständen bzw. zwei Hyperbelbahnen. (Free-free transitions.)

Eine exakte Berechnung der entsprechenden Absorptionskoeffizienten ist bis jetzt nur für Wasserstoff durchgeführt. Wir entnehmen ihr vor allem, dass das Verhältnis der $\boldsymbol{\kappa}$ von

Grenzkontinua : Bremsspektrum $=e^{n v / k T}:$ I

ist, so dass in praxi die Grenzkontinua meist den weitaus grösseren Beitrag zu $\kappa$ liefern.

Die Berechnung von $\kappa$ für die übrigen Elemente, insbesondere die Metalle, stösst z.Zt. noch auf erhebliche Schwierigkeiten. Vielleicht ist es das beste, die zahlreichen Absorptionskanten zu "verschmieren". Utbertragung der Wasserstoff-Übergangswahrscheinlichkeiten auf einzelne Metallabsorptionskanten ist ziemlich unsicher. Quantenmechanische Rechnungen ergaben z.B. für das Na-Hauptseriengrenzkontinuum eine $\sim$ I5omal kleinere Oszillatorenstärke, als man nach der "wasserstoffähnlichen" Rechnung erwarten sollte. Bei angeregten Zuständen dürften die Unterschiede jedoch geringer sein. Immerhin wäre es sehr wünschenswert, wenn die ausserordentlich langwierige Arbeit der quantenmechanischen Berechnung von $\kappa$ für alle tieferen Terme wenigstens einiger Elemente durchgeführt würde.

Neben den besprochenen Effekten könnte in kühlen Zwergsternen evt. die Wechselwirkung zwischen Elektronen und neutralen Atomen, in heissen Supergiganten evt. die Thomsonstreunng freier Elektronen von Bedeutung werden. Auch hierüber fehlen noch eingehendere Untersuchungen; wir lassen diese Effekte daher vorerst ausser Betracht.

Nachdem wir uns einen Utberblick über die derzeitigen Möglichkeiten der Theorie verschafft haben, wenden wir uns der

\section{Deutung der Beobachtungen}

zu mit dem Ziel, durch möglichst enge Verknüpfung von Beobachtung und Theorie die Schlagkraft beider Forschungsrichtungen zu erhöhen.

Den direktesten Einblick in das Zustandekommen der kontinuierlichen Sternspektren gibt uns das Studium einzelner Absorptionskanten. Sicher nachgewiesen ist bis jetzt nur die Balmerkante $\lambda_{3646}$. Durch die Messungen von Chalonge, Barbier, Kienle und deren Mitarbeitern kennen wir den Intensitätssprung $\Delta \log I$ in Abhängigkeit von Spektraltyp bzw. Temperatur der Sterne recht gut. Die Theorie lässt für die frühen Typen als Hauptfaktoren erkennen die Temperatur $T$ und das Häufigkeitsverhältnis Wasserstoff: übrige Elemente (genauer gesagt, das Verhältnis ihrer Beiträge zum kontinuierlichen Absorptionskoeffizienten). . Der Maximalwert $(\Delta \log I)_{\max }$ bei den A-Sternen kann direkt zur Bestimmung der Wasserstoffhäufigkeit herangezogen werden. Für die Mehrzahl der Sterne erhält man Werte, die gut zu den Untersuchungen von Eddington und B. Strömgren über das Sterninnere passen. Kuiper's interessante Hypothese, dass verschiedene Sternhaufen systematisch verschiedenen Wasserstoffgehalt haben, wird vielleicht direkt spektroskopisch geprüft werden können.

Die Stärke der Grenzkontinua anderer Elemente lässt sich wenigstens im Sonnenspektrum aus den gemessenen Äquivalentbreiten der zugehörigen hohen Serienglieder ermitteln, indem man von dem bekannten Gesetz der Quantentheorie Gebrauch macht, dass die Übergangswahrscheinlichkeit pro Frequenzeinheit gerechnet, sich auch an der Grenze einer Spektralserie stetig verhält. Verf. findet so für die Kanten $\mathrm{Na} \lambda 4083$ eine rel. Intensitätsabnahme $\Delta I / I$ von $0.04 \%$, für 


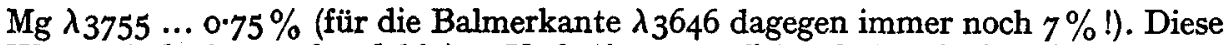
Werte sind überraschend klein. Verbreiterungseffekte hoher Serienglieder geben keine Erklärung; ebensowenig Fluoreszenz, die sich in Emission der ersten Serienglieder äussern müsste. Dagegen scheinen ziemlich erhebliche Änderungen der publizierten Berechnungen möglich sowohl hinsichtlich der angenommenen Häufigkeitsverteilungen der Elemente wie auch der Utbergangswahrscheinlichkeiten (je ein Faktor ro!) durchaus im Bereich des Möglichen zu liegen. Eine Verbesserung der quantitativen Analyse der Sonnenatmosphäre kann natürlich nur Hand in Hand mit weiterer Entwicklung der Theorie der Fraunhoferlinien und ihren physikalischen Grundlagen (Oszillatorenstärken, Dämpfungskonstanten, etc.!) erfolgen. Die Theorie der kontinuierlichen Absorption (Ü.W.) kann vielleicht in elektrischen Gasentladungen geprüft werden (Versuche von Page, Maecker).

Eine weitere Möglichkeit zur Herstellung des Kontaktes zwischen Beobachtung und Theorie gibt die Beziehung zwischen der Farbtemperatur $T_{Z}$ und der effektiven

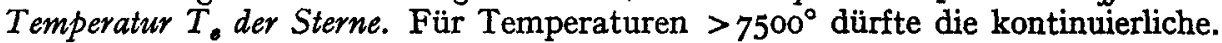
Absorption im wesentlichen von Wasserstoff herrühren. Es ist daher zu erwarten, dass im Gebiet $\lambda 4000$ bis $8000 \mathrm{~A}$. $\kappa$ nach Violett abnimmt und infolgedessen $T_{F}>T_{\text {。 }}$ wird. Neuere Messungen (Chalonge, Kienle und Mitarbeiter) geben für die Ao-Sterne eine Farbtemperatur $T_{F}$ von $\sim \mathrm{I} 4,000^{\circ}$; andererseits lässt die Deutung der Linienintensitäten kaum eine effektive Temperatur $T_{e}$ höher als $\sim$ I0,000 $\mathrm{zu}$. Die Aussage der Theorie scheint also mindestens qualitativ $\mathrm{zu}$ stimmen. Unterhalb $T \sim 7500^{\circ}$ ( $F$ bis M-Sterne) gewinnt die kontinuierliche Absorption der Metalle die Oberhand. Da $\kappa$ nun nach Violett zunimmt, erwartet man $T_{F}<T_{.}$. Eine Prüfung dieser Aussage wird sehr erschwert durch den wachsenden Einfluss der Absorptionslinien. Für die Sonne geben Messungen von Mulders und Shayn einen guten Einblick und Milne's Theorie des "blanketing effect" scheint den Einfluss der Linien auf den Strahlungs-Energietransport gut zu erfassen. Soviel aus den Beobachtungen zu entnehmen ist, steigt der für die Sonne berechnete Absorptionskoeffizient im Violetten zu stark an. Eine weitere Klärung können wohl erst neue Präzisionsmessungen der Energieverteilung im Sonnenspektrum und des Mitte-Rand-Kontrastes in Abhängigkeit von der Wellenlänge bringen. Erwähnt sei ferner noch, dass die erwähnten Rechnungen Milne's nur zutreffen, wenn die Bildung der Mehrzahl der Fraunhoferlinien nach dem Schuster-Schwarzschildschen Modell erfolgt. Dieser Punkt ist durch Untersuchung der Mitte-Rand-Variation der Linien einer direkten Prüfung zugänglich.

Sodann sei noch auf ein Problem hingewiesen, das z.Zt. wohl als grösstes Rätsel der Sonnenphysik betrachtet werden muss. Aus dem Hervortreten der Fackeln am Sonnenrand folgt, dass in diesen Gebieten die hohen Schichten der Sonnenatmosphäre überhitzt sind. Das Verschwinden der Fackeln in der Mitte der Sonnenscheibe dagegen lehrt, dass diese Uberhitzung der hohen Schichten durch eine Unterkühlung tieferer Schichten weitgehend kompensiert wird. Wie kommt nun der zusätzliche Energietransport in den Fackeln zustande? Konvektion müsste sich in Dopplereffekten äussern; nach Abschätzungen von Cowling und Siedentopf könnte sie auch kaum Temperaturunterschiede der beobachteten Grössenordnung hervorbringen. Unser Problem hängt offenbar zusammen mit dem der chromosphärischen Eruptionen und wohl auch mit den sog. "Abweichungen vom thermischen Gleichgewicht". Seine Klärung wäre nicht nur für die Sonnenphysik, sondern auch für die Geophysik von grundlegender Bedeutung.

Schliesslich sei noch kurz darauf hingewiesen, dass der kontinuierliche Absorptionskoeffizient $\boldsymbol{\kappa}$ in mehrfacher Hinsicht auch für die Theorie der Fraunhoferlinien 
von grosser Bedeutung ist. Er bestimmt (a) die wirksame Tiefe der Atmosphäre oder-anders ausgedrückt-die Gesamtzahl wirksamer Atome über I cm. ${ }^{2}$ der Sternoberfläche $\overline{N H}$. Sodann (b) geht $\kappa$ ein in die Beziehung zwischen dem mittleren Elektronendruck $P_{e}$ einer Atmosphäre einerseits und der effektiven Temperatur $T_{\text {。 }}$ sowie der Schwerebeschleunigung $g$ andererseits. Und endlich $(c)$ hängt unter bestimmten Verhältnissen auch die Restintensität der Linien mit $\kappa$ zusammen. In der Mitte starker Linien, die durch wahre Absorption entstehen (z.B. höhere Glieder der Balmerserie in A-Sternen), erhält man nämlich Strahlung entsprechend der Kirchhoff-Planck-Funktion für die Grenztemperatur des Sterns, d.h. die Restintensität ist dann gleich der Randhelligkeit des Sternscheibchens, das man in einem Super-Teleskop beobachten würde. Das Verhältnis der Intensität in der Linienmitte zu der des Kontinuums gibt also ein Mass der Randverdunkelung des Sterns und ist damit in bekannter Weise mit der Theorie des kontinuierlichen Spektrums verknüpft.

Unsere kurze Übersicht konnte zwar noch nicht sehr zahlreiche endgültige Resultate aufweisen, aber wir überblicken heute wenigstens zum grossen Teil schon die Zusammenhänge zwischen ursprünglich ganz getrennten Forschungsgebieten. Und wenn es auch dem Theoretiker heute noch nicht möglich ist, das Spektrum eines Sterns mit der effektiven Temperatur $T_{e}$ und der Schwerebeschleunigung $g$ am Schreibtisch zu berechnen, so kann er doch dem Beobachter wertvolle Fingerzeige für die sinngemässe Anlage und Auswertung seiner Beobachtungsprogramme an die Hand geben. Es ist zu hoffen, dass immer engere Zusammenarbeit von Beobachtung und Theorie in den kommenden Jahren auch die aufgezeigten offenen Probleme ihrer Lösung näher bringen wird.

\section{LITERATUR}

Zusammenfassende Darstellungen mit Literaturangaben:

H. KIEnl.e. Das kontinuierliche Spektrum der Sterne. Erg. d. exakt. Naturwiss. 16, 437-63, 1937.

A. UnSöLD. Physik der Sternatmosphären, Berlin, 1938.

An neueren Arbeiten seien erwähnt:

A. Arnulf, D. Barbier, D. Chalonge und H. Safir. Ann. Astrophys. 1, 293, 1938.

M. Minnaert und J. K. v. D. Briel. Zs. f. Ap. 15, I73, 1938.

L. Biermann. Zs. $f$. $A p$. 16, $291,1938$.

A. Unsöld. Zs. f. Ap. im Erscheinen.

Discussion. Dr Rosseland first discussed the possibility of variations in the Sun's emission in the far ultraviolet.

Dr Stratton pointed out that large changes occurring in the ionosphere of the Earth between the maxima and minima of sunspots suggest a strong increase of the far ultraviolet emission during the maxima.

Dr Vegard agreed with the importance presented by such phenomena and emphasized their importance for a more precise knowledge of the ultraviolet solar emission.

The discussion was then led back to questions more closely connected with the lecture by the following remark, made by Dr Minnaert: "We heard from Dr Unsöld that the continuous absorption is sufficiently well described by the 'smoothed' formula. But still he finds that the absorption at the series limit is much smaller for sodium and magnesium than would correspond to the formulae generalized from those for hydrogen. Must there not be other cases in which the absorp- 
tion at the series limit is stronger than what your simplified formula indicates? And if not, to what must we attribute the origin of the continuous absorption?"

The general meaning of Dr Unsöld's answer was that the theory was still in an early stage: some important phenomena, such as absorption by neutral $\mathrm{H}$-atoms and by negative ions (Wildt), are not considered; and it may be that the principles used for the derivation of the theory are not fully correct.

The discussion being closed, Dr Redman delivered the following lecture:

\section{Sources of Error in the Measurement of Line Profiles}

\section{By Dr R. O. REDMAN}

The practical problem of measuring the shape of an absorption line may be divided into two parts: (a) we have to form an image of the line and the adjacent spectrum by means of some instrument, usually a spectrograph, and $(b)$ we have to measure the distribution of light in this image.

(a) Image formation. It is essential to keep in mind that the image is not a perfectly true representation of the spectrum; there is always some distortion present. In a few favourable cases the distortion may be small, but in most instances it is considerable. For example, the most powerful spectrographs at present in active service do not allow us to measure, with errors not greater than I per cent of the continuous spectrum, solar lines of Rowland number less than 5, i.e. of equivalent width less than about $\mathrm{I} / 6 \mathrm{~A}$. The position with regard to stellar spectra is naturally much worse.

The sources of distortion may be classified into three groups:

(i) Diffraction. The amount of distortion arising from diffraction may be calculated from the optical constants of the instrument used. In general it is only of secondary importance, the performance of the spectrograph almost invariably falling considerably short of the theoretical standard.

(ii) Scattered light. Owing to reflections at air-glass surfaces, to dust, reflections on the walls and other parts of the instrument, there is generally a rather large amount of false light present, distributed more or less uniformly over the focal plane. One should diaphragm the instrument carefully, use as short a slit as practicable (especially in solar work), and, best of all, use a monochromator. For many purposes it is most convenient to measure the scattered light under standard conditions with the aid of the monochromator, which subsequently may be dispensed with, the then known corrections being inserted where required in the final results. A low dispersion monochromator is generally sufficient for use with a prism spectrograph; but with a grating it may be desirable to use one of fairly high resolving power, allowing some at least of the grating ghosts to be eliminated. Note that the importance of the scattered light varies with the region of spectrum measured and with the colour sensitivity of the light receiver.

(iii) Optical imperfections. Every spectrograph contains other imperfections besides scattered light. If we study the image of a practically monochromatic emission line, we may find in a good instrument that the centre peak has roughly the theoretical shape, but practically always there is considerably more light in the outer parts of the image than theory predicts. The reason seems to be that opticians have so far concentrated on producing the greatest resolving power, without worrying much about the filling in of the centres of absorption lines.

It is essential that we should do our best to measure this source of instrumental 
distortion. We may use narrow emission lines, selected according to the power of the instrument being tested. For example, the ordinary krypton spectrum should suffice up to resolving power of the order of 2 or $3 \times 10^{5}$ in the ordinary photographic region. There are, however, dangers in using emission lines for this purpose, when the final object is to measure absorption line profiles, and standard absorption lines would be better in many respects, were they available. Allen has used the B band of oxygen in the solar spectrum, with satisfactory results, and it was interesting to hear from Prof. Dingle that at Kensington they are now using certain absorption lines in laboratory sources. If we can find a convenient set of standard absorption lines for these tests, a saving of labour and an increase of experimental accuracy should follow.

Having measured this distortion, we may to a limited extent correct for it, generally by purely numerical methods.

Necessary improvements. We need to push up our real resolving power to at least something of the order of $10^{6}$. The chances of doing this with glass prisms or with ordinary diffraction gratings seem small. Liquid prisms have been used successfully by Evershed for wave-length measures, and a determined attack should be made on their possibilities for profile work. An alternative is the echelon grating, which has been used by Prof. Carroll with promising results in the difficult study of the structure of the chromospheric lines. The Fabry-Pérot etalon at the moment appears more suitable for emission than absorption spectra.

(b) Measurement of the image. The photographic method, for reasons which need not be enumerated here, remains supreme, although the photographic plate still has very definite limitations. Assuming we are aiming at the highest accuracy, it is essential to be very careful in manipulating the plate and especially in obtaining the characteristic curve, where the effect of varying exposure time and other factors has to be watched carefully. In general, the rule seems to be that greater care is required as speed and colour sensitivity are increased.

Owing to its finite resolving power, the photographic plate itself distorts the spectrum image, the effect becoming very marked in the case of small dispersion spectrographs. Normally it is convenient to treat the photographic distortion as a part of the instrumental distortion.

With regard to development, it would be of considerable interest to know if any member of this Commission has tested thoroughly, from the point of view of accurate photometry, some of the fine-grain developers now widely used for miniature cameras. Are these developers worth while, when one takes into consideration the verdict of the microphotometer with regard to grain, the accuracy and uniformity of the results, freedom from Eberhard effect, etc.?

With regard to microphotometers, the great majority of instruments now in use appear to be more accurate than the photographic plate. The present system of making tracings in some arbitrary instrumental parameter, and subsequently reducing these with much labour to curves in intensity or $\log$ (intensity) leaves much to be desired, and the recently published invention of an almost automatic machine by Prof. Minnaert and Mr Houtgast is very welcome. Dr Dunham has been engaged for some time at Mt Wilson in the design of a fully automatic instrument, and at Cambridge we also have devoted much thought to the same problem. To produce such a machine seems quite practicable, so that, given a suitable plate calibration, tracings may be made directly in terms of any desired parameter.

There are two important practical difficulties provided respectively by line wings and by blends. With regard to the latter, we may possibly expect the theorists to 
come to our rescue, rather than that the observer should attempt to separate blended lines by some empirical method, giving results which may be of doubtful physical significance.

Finally a word should be said concerning the use of photoelectric methods of measurement of the line image. Even if used simply as a check on photographic results, these would be valuable, but it appears possible that they can also give higher accuracy of measurement than can the photographic plate. Dr Dunham is now pursuing further his early work along these lines, while at Cambridge Dr Brück is starting observations by this method. We may expect very useful results from these investigations.

Discussion. To Dr Redman's question concerning the use of an echelon Dr Carroll answered that there is no difficulty in using an echelon to investigate emission lines. He gave a short description of a different device, with Fabry and Perot plates, which would be better fitted to the study of absorption lines. Dr Carroll insisted upon the importance of the determination of the profiles of some lines with as great an accuracy as possible.

After a short remark by Dr Merrill, the Chairman returned his thanks to Dr Unsöld and Dr Redman for their very interesting papers, and the meeting was closed. 